\title{
INTRA-INDUSTRY TRADE IN THE VISEGRAD COUNTRIES: DOES THE LINDER HYPOTHESIS HOLD?*
}

\author{
Martin GRANČAY - Nóra GRANČAY - Jolita VVEINHARDT
}

(Received: 20 August 2014; revision received: 17 February 2015; accepted: 8 June 2015)

\begin{abstract}
In 1961, Staffan Linder attacked mainstream trade economics by diverging from the generally accepted factor endowments theory and focusing on alternative explanations of why countries trade with each other. He was among the first economists to recognise the growing importance of intraindustry trade and presented his hypothesis that the more similar the per capita income levels of countries, the more they tend to trade with each other. This observation has since become one of the main pillars of modern trade theory. The present paper assesses the empirical validity of the Linder hypothesis in the Visegrad countries. Using a variant of the gravity model, it finds that when controlling for other factors, the Visegrad countries tend to trade more with countries with similar per capita income levels than with significantly richer or poorer countries. This observation is consistent with the Linder hypothesis. OLS regressions, Tobit regressions, and robustness checks all support the hypothesis.
\end{abstract}

Keywords: Linder hypothesis, intra-industry trade, gravity model, Visegrad countries

JEL classification index: F11

* This research was funded by the Cultural and Educational Grant Agency of the Ministry of Education, Science, Research and Sport of the Slovak Republic (Grant No. 017EU-4/2015). The authors would like to thank Rachael Leuenberger for revising the English text.

Martin Grančay, corresponding author. Assistant Professor at the Faculty of International Relations, Department of International Economic Relations and Economic Diplomacy, University of Economics in Bratislava, Slovak Republic. E-mail: martin_grancay@yahoo.com

Nóra Grančay, Assistant Professor at the Faculty of International Relations, Department of International Economic Relations and Economic Diplomacy, University of Economics in Bratislava, Slovak Republic. E-mail: nora.grancay@gmail.com

Jolita Vveinhardt, Chief Researcher at the Institute of Sport, Science and Innovations, Lithuanian Sports University, and Associate Professor in Vytautas Magnus University, Lithuania.

E-mail: Jolita.Vveinhardt@gmail.com 


\section{INTRODUCTION}

In 1961, a young Swedish economist, Staffan Linder received a PhD degree for his dissertation, "Essay on Trade and Transformation", in which he showed the importance of demand patterns on international trade. Because it was probably a little ahead of his time, the work did not receive due attention until the end of the 1970s thanks to the emergence of a new trade theory. Today, it is considered as one of the pillars of modern trade theory.

The Linder hypothesis constituted an attack on the conventional comparative advantage and Heckscher-Ohlin theories. It was a direct response to a new situation in the world economy in the 1950s, in which developed countries increased their mutual trade by trading similar goods. This trade, called intra-industry trade, could not be explained by traditional supply-based theories. Under these circumstances, Linder developed what could be described as the first demand-based theory of international trade.

In its simplest form, the Linder hypothesis states that the more similar the per capita income levels of countries are, the more they tend to trade with each other. Linder argued that countries usually export goods for which they have large domestic demand. The analytical underpinnings of the hypothesis remained unclear at the time of its publication (Grossman - Rogoff 1995). Later, economists demonstrated that the domestic demand enables companies to standardise product features and lower unit costs, and that after the product is well-established in the domestic market, business opportunities are sought abroad to further reduce unit costs and increase profits. Linder argued that export markets are chosen based on consumer preferences - the product will be exported to countries where consumers have similar preferences to consumers at home. Per capita income similarity is used as a proxy for the similarity of preferences.

In Linder's theory, consumer preferences are based on product quality. The mechanism is simple. Countries with a high income per capita spend a higher fraction of their income on high-quality goods than lower-income countries. This enables them to develop a comparative advantage in high-quality goods. Hence, as a result of high demand, high-income countries focus on high-quality goods and, conversely, low-income countries focus on low-quality goods. It follows that countries with a similar level of per capita income tend to trade with each other more than with other countries because they require a similar quality of goods.

It has been long established that the Linder hypothesis holds true only for highincome countries (e.g. Hanink 1990). Indeed, Linder himself suggested that his theory applies only to trade in differentiated manufactured goods, as opposed to trade with agricultural goods or natural resources. High-income countries tend to trade with differentiated manufactured goods where the role of consumer prefer- 
ences is important. Conversely, low-income countries mostly trade with natural resources where consumer preferences play no role. As all four Visegrad countries - the Czech Republic, Hungary, Poland, and the Slovak Republic - belong to the upper middle/high-income world and have an above average share of intraindustry trade, they are an ideal sample for testing the hypothesis.

The aim of this paper is to study the empirical validity of the Linder hypothesis in the Visegrad countries in the post-socialist period. The results are based on a variant of the gravity model of trade. As is standard in literature, we focus on international trade in goods only and do not take into account international trade in services. While it is indisputable that trade in services has significantly increased in importance since Linder's times, it is governed by slightly different principles than international trade in goods. Moreover, trade in goods still represents fourfifths of total global trade and its share has not been diminished by services in the past decade (WTO 2014).

The contributions of our research are threefold. (1) It presents an addition to the current trade literature, as the first paper to consider the Linder hypothesis in the context of post-communist countries in the transition period. (2) The hypothesis is tested in three time periods $(1995,2003,2013)$, it includes several control variables, and it therefore offers insights into how the importance of individual determinants of trade has changed over time. (3) It briefly shows how intra-industry trade developed in the Visegrad region between the years 1995 and 2013, and identifies partners with the highest potential of intra-industry trade growth in the future.

The rest of the paper is structured as follows. Section 2 offers a literature review of the major tests of the Linder hypothesis. Section 3 presents the model used and answers some important questions about modelling choices. Section 4 shows how intra-industry trade has developed in the Visegrad region in the last two decades. The results of the research along with robustness checks, implications for policy-makers, and the drawbacks of the research are presented in Section 5 , followed by a short conclusion.

\section{LITERATURE REVIEW}

Over the last few decades, several studies assessing the validity of the Linder hypothesis have been published. It quickly became clear that the first tests applying rank correlation, but not controlling for distance, were methodically incorrect (e.g. Sailors et al. 1973). As a result, the most commonly used test method today is based on modified gravity-type models, where standard independent variables are complemented by a carefully selected per capita income similarity 
variable. The volume of bilateral intra-industry trade is normally used as the dependent variable. The most prominent studies using gravity-type models include Thursby - Thursby (1987), Hanink (1988), Francois et al. (1996), McPherson et al. (2001), Chow (2002), and Hallak (2010). Most of these studies have found at least a partial support for the Linder hypothesis. This support is usually based on the findings of a negative and statistically significant coefficient on the incomesimilarity variable (McPherson et al. 2001). However, the sign of the coefficient depends on how the variable is constructed. As we will see later in the paper, in our case, a positive and statistically significant coefficient is required.

Thursby - Thursby (1987) used a sample of 17 OECD countries for the period of 1974-1982 to test the hypothesis. Their gravity model found "overwhelming" support for the Linder hypothesis in 15 of the studied countries, the only exceptions being Canada and South Africa. Since they used data for all merchandise exports, these exceptions can easily be explained by the fact that the two countries export mainly primary commodities and it cannot therefore be expected that their patterns of trade would fit Linder's predictions.

Hanink (1988) performed an extensive test of the Linder hypothesis on a set of 26 countries. He concluded that trade intensity (a proxy he uses as a dependent variable) is "an increasing function of market homogeneity [and] a decreasing function of distance", as expected by the Linder model. Additionally, Hanink incorporated goods variety into the model and found that trade intensity is an increasing function of variety across goods.

The scope of Bergstrand's 1990 paper is rather broad, yet one of his main conclusions is that "the share of intra-industry trade will be lower the greater the inequality between two countries' per capita GDPs".

Chow et al. (1999) focused on trade between selected OECD members and newly industrialised countries of East Asia. Using an extensive disaggregate data set spanning more than two decades, their time-series analysis found some support for the Linder hypothesis. While the support appears to be weak and there are other key factors contributing to trade patterns, they still consider it better than expected given the method used.

McPherson et al. (2001) tested the Linder hypothesis on six East African developing countries. Their results showed that five of the studied countries tended to trade more with countries with similar levels of per capita GDP than with other economies, which is in line with Linder's predictions.

Most recently, Hallak (2010) tested the hypothesis on a sample of 64 countries using data for 1995 . He criticised the "aggregate" view of the Linder hypothesis and suggested that only sectorial-level tests are methodically correct. He assumed that quality supply and quality demand are systematically related to income per 
capita, and modelled the interaction of demand for and supply of quality within sectors (for example, he distinguished between high-quality and low-quality cars). Controlling for the effect of inter-sectorial determinants of trade, his research confirmed that countries of similar per capita income trade more intensely with one another.

Other authors failed to confirm the validity of the Linder hypothesis empirically. Kennedy - McHugh (1980) studied 14 industrialised countries using data for a 16-year time period, but with no positive result. Hoftyzer (1984) found a strong and statistically significant effect of distance and membership in free trade areas on bilateral trade flows, but was unable to prove the significance of per capita income similarity. Linnemann - van Beers (1988) did not find sufficient evidence to support the hypothesis either.

Interestingly, many of the tests conducted in the 1980s rejected the Linder hypothesis, while the majority of recent research supports it. This paradox was explained by Chow (2002), who performed a rather extensive test using an enlarged data set of 63 countries. He not only came to the conclusion that the coefficients of Linder variables are statistically significant, but he also showed that they grow as time goes by, which "can partly explain some of the earlier empirical results that rejected the Linder hypothesis and recent results supporting it" (Chow 2002: 604). Another reason for the failure of older tests to confirm the thesis was formulated by Hallak (2010: 453), who showed that "aggregation across sectors induces a systematic bias against finding support for Linder's quality-base theory". The theory should therefore be tested using disaggregate data, which the older tests did not do. Another oft-cited problem with older tests is the issue of zero trade flows, which in most cases were simply omitted from calculations, thus creating inconsistencies and bias.

\section{THE MODEL}

As shown in the previous section, almost all published tests of the Linder hypothesis have been based on gravity-type models. Gravity models are therefore an obvious choice for further regional tests of the theory, including ours. However, this does not mean that testing will be straightforward. On the contrary, there are several crucial questions that need to be answered: (1) Will the test be performed on aggregate or sectorial level? (2) How will intra-industry trade be calculated? (3) What measure of per capita income similarity will be used? (4) What variables should be included in the model? (5) How to deal with zero trade flows? 


\subsection{Aggregate vs. disaggregate data}

The answer to the first question is determined by the objectives of the research and data availability. Bilateral sectorial-level trade statistics are known to be notoriously inconsistent. They include a high number of zero trade flows, among which it is difficult to distinguish true zeroes from rounding adjustments and incorrectly reported data. For example, in the case of the Slovak 2013 trade matrix, based on UNCTAD (2014) three-digit level SITC, Rev. 3 commodity classification data (255 products and 222 countries/areas), 69\% out of 56,610 values are zeroes. While the majority of these are certainly true zeroes, there is an unknown, but probably substantial number of rounding adjustments and misclassified values. Groups 664 - Glass, 665 - Glassware, and 666 - Pottery are an example of often misclassified items. As a result of these problems with disaggregate data, we chose to perform our analysis on the aggregate level. This enables us to use relatively simple regression methods and has the additional effect of including a bias against the Linder hypothesis - should the analysis find support for the hypothesis, its significance will be higher than if performed on the disaggregate level. (Of course, the case of hypothesis rejection is more complicated - if no support for the hypothesis is found on the aggregate level, due to the bias additional analysis with disaggregate data will have to be performed.)

\subsection{Intra-industry trade - the dependent variable}

Several approaches exist to calculate the volume of bilateral intra-industry trade. One of the simplest ones, used for example by McPherson et al. (2001), is to use developing countries' total imports as a proxy for intra-industry trade. This is based on the notion that the majority of developing countries' imports are comprised of manufactured goods, which are considered synonymous with intra-industry trade. Obviously, this approach is oversimplified, it can lead to important inaccuracies, and cannot be used with developed countries at all. The authors themselves admit that total imports also include a proportion of goods that are not consistent with the Linder effect, such as primary products. Moreover, not all trade with manufactured goods can be considered intra-industry. A similar problem occurs when exports are used as the dependent variable (e.g. Thursby Thursby 1987; Chow 2002).

Other branches of literature use trade indices as explanatory variables. Hanink (1988) chooses trade intensity, defined as the common logarithm of the per capita imports of country $i$ 's goods by country $j$. Chow et al. (1999) opt for trade complementarity index, which measures the extent to which each exporter's commodity 
export pattern matches the respective market's commodity import patterns more closely than it matches the commodity composition of the total reference group's imports. These trade indices are specifically designed to be used in product-level gravity models and their application for aggregate models is unsuitable.

In the present paper, we use a measure of intra-industry trade based on the combination of total trade and trade indices. One of the most widely used indicators of intra-industry trade is the simple Grubel-Lloyd index developed in the early 1970s. The index is calculated as:

$$
G L_{i k}=1-\frac{\sum_{k=1}^{n}\left|X_{i k}-M_{i k}\right|}{\sum_{k=1}^{n}\left(X_{i k}-M_{i k}\right)}
$$

where $X$ is export, $M$ is import, $i$ is the country index and $k$ is the product index. The Grubel-Lloyd index takes values between 0 and 1 . If the GL of a country is 0 , the country has no intra-industry trade. If $\mathrm{GL}=1$, the entire trade of the country is intra-industry trade. The Grubel-Lloyd index can also be calculated for bilateral trade between two countries - it indicates the approximate portion of mutual trade that is intra-industry. Hence, if in trade between Hungary and Finland GL = 0.17 , approximately $17 \%$ of mutual trade is intra-industry trade.

The most often cited problem of this approach is that it is accurate only if trade is balanced. Several new indicators have been developed to mitigate this issue (Grubel et al. 1975; Aquino 1978; Vona 1991, to mention a few). However, as shown by Brülhart (2009), these new indicators lead to other types of inconsistencies and it is therefore recommendable to stick with the original GL index. Instead of using these indicators, we will make a simple adjustment to the original GL index to address the trade imbalances issue - values of product-level imports and exports in equation (1) will be replaced by shares of the products in total imports and exports. The total value of mutual intra-industry trade can then be easily calculated by multiplying total trade by the adjusted GL index. This is the measure the present paper uses as a dependent variable (IIT $)_{1} \cdot{ }^{1}$ We will also use an additional dependent variable, calculated in the same way as IIT ${ }_{1}$, but using the original GL index instead of the imbalance-adjusted one ( $\left.\mathrm{IIT}_{2}\right)$.

Obviously, the values of the measure depend on the level of data aggregation. We use threedigit level SITC, Rev. 3 commodity classification throughout the paper. 


\subsection{Income similarity - the explanatory variable}

To measure the degree of similarity between per capita incomes of the studied countries, economists usually opt to compare the countries' GDP. While some studies use absolute value of the difference in the levels of real per capita GDP (Thursby - Thursby 1987; McPherson et al. 2001) or per capita GNP (Hanink 1988), others prefer the ratio of the difference in per capita GNP to the sum of the exporting and importing country's per capita GNPs (e.g. Chow 2002).

Using absolute difference in per capita income levels does not appear to be suitable for testing the Linder hypothesis. This approach fails to understand the importance of relating differences to the absolute value of income. Two pairs of countries can have the same income gap of USD 3,000; however, this is a negligible difference for high-income countries and an enormous difference for their low-income counterparts. In 2012, nominal GDP per capita in Canada was USD 52,000 and USD 55,000 in Sweden. The incomes of Canadians and Swedes were thus obviously highly similar. Income difference between Egypt and Somalia was also USD 3,000, but at USD 3,200, the income of Egyptians was 16 times higher than the income of Somalis; nowhere close to similar.

Chow's approach of using the ratio of the difference in per capita income to the sum of the exporting and importing country's per capita incomes is methodically correct. In the present paper, we will use a similar, yet simpler way to measure income similarity - we calculate the ratio of the exporting and importing country's per capita GDPs, the smaller of the two always being the numerator and the larger of the two always being the denominator:

$$
G D P \operatorname{sim}=\frac{\min \left(G D P_{X} ; G D P_{M}\right)}{\min \left(G D P_{X} ; G D P_{M}\right)} .
$$

Our measure is highly correlated with the Chow's indicator of income similarity; indeed, their Spearman rank correlation value is -1 and their Pearson correlation value -0.94 . Chow's indicator will be used later in the paper for a robustness check.

\subsection{Independent variables}

All gravity models of trade traditionally include three key independent variables: the exporter's GDP (or GNP), the importer's GDP (or GNP), and the distance between the exporter and importer. They also typically include a set of additional variables that are deemed necessary to be controlled for in order to reach mean- 
ingful and economically significant results, or they are included in the model to test their statistical significance. These variables range from population size, tariff rate, applied inflation, and exchange rate to numerous dummy variables such as common language, common colonial history, insularity, common border, free trade areas, political risk, etc.

In the present paper, income similarity is the independent variable of interest and the one to be tested. Independent variables we control for include GDP, distance, applied tariffs and dummies for membership in the European Economic Area (EEA), common land border, and landlockedness. Other variables - perhaps because this research is limited to the four culturally close and economically interconnected Visegrad countries - were found to be statistically insignificant in preliminary testing.

\subsection{Zero trade flows}

One of the most discussed issues of gravity modelling is how to handle zero trade. This is a serious problem because gravity models of trade are usually based on a log-linear equation and the log of zero is not defined. There have been at least five approaches to handle this issue: (1) truncating the sample by dropping the observations with zero trade, (2) adding a small constant to the value of trade before taking logarithms, (3) estimating the model in levels, (4) estimating the model using Tobit, and (5) estimating the model using Poisson maximum likelihood (WTO 2012). All of these approaches have received some criticism.

The first approach has traditionally been the most popular in literature. While omitting zero flows can bias the empirical results if the zeroes do not occur randomly, this does not have to be a serious issue if the method is carried out carefully. In the present paper, we focus on four central European countries only. This limits the amount of data in the data set and makes it relatively easy to distinguish between "true zeroes" and unreported/misreported values by comparing them with other databases. To be able to include these "true zeroes" in the analysis, we add a small constant (1) to the value of trade flows and hence are able to obtain logarithms. Understandably, this might lead to a minor bias in the model. However, this bias will only be a source of concern if the present research rejects the Linder hypothesis. Should we find support for the hypothesis, the bias will constitute no problem for the validity of the research because it operates against the hypothesis.

Apart from the simple method described above, more elaborate approaches are sometimes chosen to deal with the issue of zero trade flows. Estimating the model in levels is one of the options, yet it was shown to be incorrect (WTO 2012). 
Theoretically, the Tobit and Poisson maximum likelihood analyses are more grounded. In the present research, a Tobit estimator with left-censoring at zero on the log of trade will be employed.

\subsection{The model}

Having answered all the crucial questions, our model takes the following form:

$$
\begin{aligned}
& \operatorname{lnIIT}_{i j}=b_{0}+b_{1} \cdot \ln G D P_{j}+b_{2} \cdot \ln \text { Dist }_{i j}+b_{3} \cdot \ln G D \text { Psim }_{i j}+b_{4} \cdot \text { Tariff }_{j}+ \\
& b_{5} . \text { Dum_EEA }{ }_{j}+b_{6} \cdot \text {.nDum_contig }{ }_{i j}+b_{7} \cdot \ln \text { Dum_land }_{j}+\varepsilon \text {. }
\end{aligned}
$$

where $I I T$ is intra-industry trade, $G D P$ is expressed in terms of millions of current dollars, Dist is distance between the countries in kilometres, GDPsim is similarity of per capita incomes, Tariff is the weighted mean applied tariff, and the three dummy variables indicate whether the partner is a member of the EEA, has a common border with the V4 country in question, and whether it is a landlocked country (Table 1). The variable of interest is GDPsim. If we find its coefficient to be positive and statistically significant, this will indicate that controlling for other factors, V4 countries tend to trade more with countries with similar levels of per capita GDP than with other economies.

\begin{tabular}{|c|c|c|}
\hline Variable & Description & Source of data \\
\hline $\mathrm{IIT}_{1}$ & $\begin{array}{l}\text { Bilateral intra-industry trade calculated using the Grubel- } \\
\text { Lloyd index adjusted for trade imbalances }\end{array}$ & $\begin{array}{l}\text { UNCTAD (2014) } \\
\text { Own calculations }\end{array}$ \\
\hline $\mathrm{IIT}_{2}$ & $\begin{array}{l}\text { Bilateral intra-industry trade calculated using the standard } \\
\text { Grubel-Lloyd index }\end{array}$ & $\begin{array}{l}\text { UNCTAD (2014) } \\
\text { Own calculations }\end{array}$ \\
\hline GDP & Nominal Gross Domestic Product & UNCTAD (2014) \\
\hline GDPcap & Nominal Gross Domestic Product per capita & UNCTAD (2014) \\
\hline GDPsim & $\begin{array}{l}\text { Similarity between GDPcap of two countries, } \\
\text { calculated as lower GDPcap divided by higher GDPcap }\end{array}$ & $\begin{array}{l}\text { UNCTAD (2014) } \\
\text { Own calculations }\end{array}$ \\
\hline Dist & Various indicators. See the main text. & CEPII (2011) \\
\hline Tariff & Weighted mean applied tariff & World Bank (2014a) \\
\hline $\begin{array}{l}\text { Dummies: } \\
\text { Dum_EEA } \\
\text { Dum_contig } \\
\text { Dum_landl }\end{array}$ & $\begin{array}{l}\text { Member of the EEA } \\
\text { Common border } \\
\text { Landlocked country }\end{array}$ & $\begin{array}{l}\text { Own data } \\
\text { CEPII (2011) } \\
\text { CEPII (2011) }\end{array}$ \\
\hline
\end{tabular}

Table 1. Data sources

Source: Own research. 
Following a standard approach of mirroring, all trade data used are imports. Hence, Hungarian imports from Slovakia and exports to Slovakia are taken from the UNCTAD (2014). No data is taken from export tables. This is done in order to avoid inaccuracies commonly associated with export data, which are monitored less carefully by customs administrations than import data. All trade and product data used are nominal, i.e. measured in current dollars at current exchange rates. The three-digit level SITC, Rev. 3 commodity classification is used.

Distance data is taken from the database compiled by the CEPII (2011). A complex measure (distwces) is employed, based on bilateral distances between the biggest cities in two countries, weighted by the share of the city in the country's overall population. For the robustness check, simple great circle distances between main agglomerations and remoteness are used as alternate distance variables. A weighted mean applied tariff is used to measure the degree of trade protectionism countries apply in their foreign trade.

Data are available for the years 1995, 2003 and 2013, which enables comparison over time. If no data were reported for the specified years (this is often the case with the Tariff indicator), the most recent figures were used. The number of countries and territories included in the study (based on the data availability) ranges from 67 in 1995 to 160 in 2013. All regressions are conducted on a joint set of data for all four Visegrad countries.

\section{INTRA-INDUSTRY TRADE IN THE VISEGRAD REGION}

Before proceeding with the test of the Linder hypothesis itself, it is not without interest to briefly present the Visegrad countries' structure of trade, with a special focus on how intra-industry trade in the Visegrad region developed in the last two decades.

With the exception of Polish coal, none of the Visegrad countries possess significant reserves of natural resources. As a result, since the socialist times, the Czech Republic, Hungary and Slovakia have all been focusing on industrial production. Czechoslovakia was one of the most advanced economies of the socialist bloc, producing mainly producer goods, but also several popular consumer goods (such as Škoda cars). Compared to the Czech Republic, Hungary was more agriculturally oriented, but due to different political developments, she was able to start the process of economic reforms in the 1980s, almost a decade earlier than the majority of other socialist countries. Some basic market reforms had already started as early as 1968 (Györffy 2009). The currency reform in 1981, the International Monetary Fund entry in 1982, the introduction of a bankruptcy law in 1986, the banking reform in 1987, and the approval of a new commercial 
code in 1988 were some of the main factors that led to an increase in private economic activities in the 1980s (Zídek 2014), a growth of industrial production, and an early entry of the first important foreign direct investors to Hungary (such as Suzuki and GE Lighting). The situation in Poland was different, yet in some ways similar - thanks to the reforms undertaken in the 1980s, the private sector accounted for more than a quarter of economic activity in 1989 (Lane 1992). Hence, none of the Visegrad countries were a text-book example of a centrally planned economy when the transition occurred (Dudás 2004).

All these factors, combined with a rapid inflow of merchandise and investors from Western Europe after the fall of the Iron Curtain, led to a relatively high share of intra-industry trade in the Visegrad countries in the 1990s. Moreover, it is well established that small countries tend to have higher trade openness than large countries (Tang 2011); for small countries with limited natural resources, this translates into a high level of intra-industry trade. It is therefore not surprising that in 1995, Visegrad countries were already in the top 40 of the world regarding rankings of intra-industry trade, the Czech Republic being in the $9^{\text {th }}$ place, Hungary in the $20^{\text {th }}$, Slovakia in the $26^{\text {th }}$, and Poland in the $34^{\text {th }}$, with values of the Grubel-Lloyd index ranging from 0.63 to 0.41 .

Post-socialist economic reforms in the Visegrad countries had the goal of attracting foreign investors. While each country's performance results from a different combination of reforms, in general all of them have been successful. A large influx of foreign direct investment (FDI) has shaped the Visegrad countries' economic structures and their structures of international trade. Apart from services, investors have focused mainly on manufacturing, taking advantage of high labour productivity and relatively low wages in the region. Automotive and electronic sectors have become especially prominent. Motor vehicles, engines, and their parts constitute $17 \%$ of the region's exports (UNCTAD 2014). In Slovakia, the automotive industry generates more than $25 \%$ of the country's exports. Other important production and export items include telecommunication equipment (all), TV receivers (Slovakia, Poland), computers and their parts (Czech Republic, Hungary), and furniture (Poland). All of these sectors are typical examples of the so-called Linder goods (i.e. goods that are differentiated and demonstrate high income elasticity) and are therefore major generators of intra-industry trade; along with natural resources, they also belong among the top import items.

The main export market of all the Visegrad countries is Germany, the economic powerhouse of Europe; its share in Visegrad exports ranges from 21\% in Slovakia to more than $31 \%$ in the Czech Republic. Intra-Visegrad trade is also significant and constitutes $16 \%$ of the total trade. Other important export partners, especially for Poland, are the USA and France. The list of major import partners is similar, with three noteworthy exceptions. First, Russia is the main provider of oil, gas, 
and some other natural resources to the region, and hence is the second biggest import market (10\%) after Germany (23\%). Second, imports from China have grown continuously (9\%) and are expected to surpass imports from Russia in the next two years. Third, home countries of major foreign investors in the region, such as South Korea, the Netherlands and Japan, have a disproportionately large share in imports.

Currently, all of the Visegrad countries belong to the top 20 countries with the highest values of intra-industry trade index in the world (Table 2). Hungary and the Czech Republic top the list, being at the $7^{\text {th }}$ and $8^{\text {th }}$ place globally, followed by Poland and Slovakia. The fact that the countries are at a similar level with the Netherlands or Singapore might seem surprising. However, it is a well-grounded result of their economic geography, size, economic development during socialist times, and post-socialist economic reforms.

Since 1995, the role of intra-industry trade in the Visegrad countries has been on the rise (Figure 1). The average value of the Grubel-Lloyd index has increased from 0.52 in 1995 to 0.67 in 2013 , which translates into a $29 \%$ growth in the importance of intra-industry trade, compared to a mere $15 \%$ growth of the world average. While observable in all four countries, the growth has been mostly powered by Poland and its rapid industrialisation. A clear trend towards convergence among the four countries can be identified.

Table 2. Top 10 countries and territories with the highest and lowest values of the Grubel-Lloyd index, 2013

\begin{tabular}{llll}
\multicolumn{1}{c}{ Highest GL index } & Value & \multicolumn{1}{c}{ Lowest GL index } & Value \\
\hline 1. Belgium & 0.7547 & 1. Mauritania & 0.0181 \\
2. Gibraltar & 0.7532 & 2. Mongolia & 0.0161 \\
3. Netherlands & 0.7409 & 3. Chad & 0.0161 \\
4. United Kingdom & 0.7192 & 4. Brunei Darussalam & 0.0158 \\
5. Singapore & 0.7114 & 5. Falkland Islands (Malvinas) & 0.0126 \\
6. Austria & 0.7086 & 6. Sint Maarten (Dutch part) & 0.0122 \\
7. Hungary & 0.7044 & 7. Palau & 0.0103 \\
8. Czech Republic & 0.6971 & 8. Wallis and Futuna Islands & 0.0099 \\
9. France & 0.6947 & 9. Iraq & 0.0093 \\
10. Slovenia & 0.6818 & 10. Tokelau & 0.0012 \\
.. & & & \\
13. Poland & 0.6618 & & \\
19. Slovakia & 0.6094 & & \\
\hline
\end{tabular}

Notes: Calculated at the three-digit level of SITC, Rev. 3 commodity classification.

Source: Own calculations based on UNCTAD (2014). 


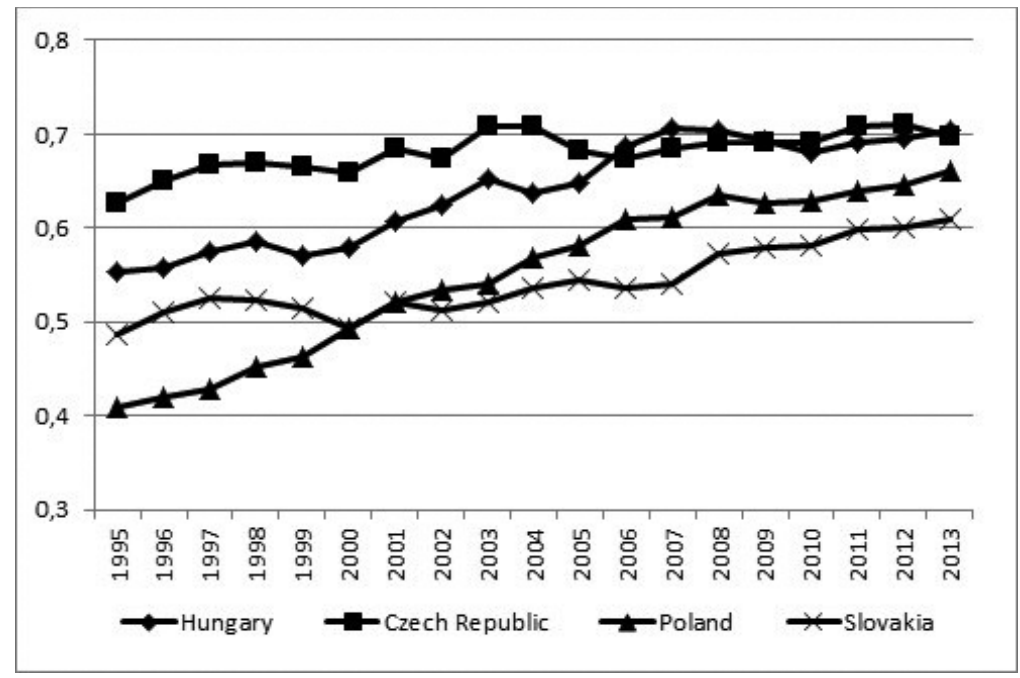

Figure 1. Grubel-Lloyd index in the Visegrad countries, 1995-2013

Note: Calculated at the three-digit level of SITC, Rev. 3 commodity classification.

Source: Own calculations based on UNCTAD (2014).

An important aspect that defines the intra-industry trade (IIT) of a country is its nature. Horizontal IIT is an exchange of differentiated goods with similar qualities such as cars of similar class, shirts of the same quality, or television receivers. Vertical IIT involves the exchange of final goods of different qualities (e.g. sedans and sports cars), or the exchange of final goods and intermediate products manufactured in the same industry. In trade between developed countries, horizontal IIT is expected to dominate. However, numerous studies have shown that trade of the Visegrad countries is dominated by vertical IIT (Černoša 2007; Fertő 2007; Jámbor 2014), especially by its lower-quality segment (Kawecka-Wyrzykowska 2009). This indicates that one of the primary drivers of the Visegrad IIT might be the relatively low labour costs in the region.

Industries with the highest contribution to the intra-industry trade in the Visegrad region (telecommunication equipment, electrical machinery, paper manufactures, organic chemicals, and transport equipment) are also the industries which have some of the highest share of FDI. This is in line with the results of previous research in this field, which show that there is a significant positive relationship between vertical intra-industry trade and FDI (Yoshida et al. 2009) and support the low-labour-cost hypothesis. As expected, the lowest intra-industry trade can 
be observed in the industries linked to natural resources such as petroleum, natural gas or coal.

Having shown the importance of intra-industry trade in the Visegrad region and its trend of development, we will now proceed to analyse how the bilateral intra-industry trade of the region's countries conforms to predictions of the Linder hypothesis.

\section{RESULTS}

The basic feature of each gravity model of trade is a negative and statistically significant coefficient on the distance and a positive and statistically significant coefficient on the economic output variable. This is a mathematical formulation of the well-known fact that mutual trade between countries tends to decrease with distance and increase with the economic size of the countries. All the models presented in the next section fulfil this requirement, which is the first indication of their economic significance.

\subsection{OLS regression}

The results of ordinary least squares regressions indicate a strong support for the Linder hypothesis (Table 3). The coefficients on the income similarity variable are positive and statistically highly significant, which means that controlled for GDP, distance and other variables, the Visegrad countries tend to trade more with countries with similar GDP per capita levels than with considerably richer or poorer countries. This result is valid for both dependent variables (intra-industry trade adjusted for trade imbalances IIT $_{1}$ and intra-industry trade without tradebalance adjustments $\mathrm{IIT}_{2}$ ) for the years 2013 and 2003 (models 2, 3, 5 and 6). However, the claim is not valid for the year 1995 (models 1 and 4). This might be a consequence of lower data availability for the period, but most likely is a result of the fact that the Visegrad countries were undergoing a process of economic and political transition in the 1990s. In 1995, only Hungary was a long-established upper-middle income country (World Bank 2014b). Slovakia and Poland belonged to the lower-middle income economies and the Czech Republic was in the process of graduating from the group. Trade patterns were influenced by large-scale privatisation projects, relatively protectionist trade policies, and deep changes in domestic entrepreneurship. Production capacities of the countries were experiencing restructuring from a post-socialist to a free market system. 
Table 3. OLS regression results

\begin{tabular}{|c|c|c|c|c|c|c|}
\hline & \multicolumn{3}{|c|}{ Dependent variable: $\ln$ IIT $_{1}$} & \multicolumn{3}{|c|}{ Dependent variable: $\ln$ IIT $_{2}$} \\
\hline & $\begin{array}{c}(1) \\
1995\end{array}$ & $\begin{array}{c}(2) \\
2003\end{array}$ & $\begin{array}{c}(3) \\
2013\end{array}$ & $\begin{array}{c}(4) \\
1995\end{array}$ & $\begin{array}{c}(5) \\
2003\end{array}$ & $\begin{array}{c}(6) \\
2013\end{array}$ \\
\hline ln_GPD & $\begin{array}{l}1.1717 * * * \\
(0.0481)\end{array}$ & $\begin{array}{l}1.4409^{* * *} \\
(0.0390)\end{array}$ & $\begin{array}{l}1.2545^{* * *} \\
(0.0413)\end{array}$ & $\begin{array}{l}1.1600^{* * *} \\
(0.0488)\end{array}$ & $\begin{array}{l}1.4532 * * * \\
(0.0408)\end{array}$ & $\begin{array}{l}1.2794 * * * \\
(0.0409)\end{array}$ \\
\hline ln_Dist & $\begin{array}{l}-1.4397^{* * *} \\
(0.1648)\end{array}$ & $\begin{array}{l}-1.3158^{* * *} \\
(0.1397)\end{array}$ & $\begin{array}{l}-1.4193 * * * \\
(0.1467)\end{array}$ & $\begin{array}{l}-1.5331^{* * * *} \\
(0.1554)\end{array}$ & $\begin{array}{l}-1.3465^{* * *} \\
(0.1471)\end{array}$ & $\begin{array}{l}-1.4658^{* * *} \\
(0.1299)\end{array}$ \\
\hline ln_GDPsim & $\begin{array}{c}0.0299 \\
(0.1456)\end{array}$ & $\begin{array}{l}0.4545^{* * *} \\
(0.1119)\end{array}$ & $\begin{array}{l}0.3302 * * * \\
(0.1052)\end{array}$ & $\begin{array}{c}0.0109 \\
(0.1501)\end{array}$ & $\begin{array}{l}0.4805^{* * *} \\
(0.1165)\end{array}$ & $\begin{array}{l}0.4081 \text { *** } \\
(0.1071)\end{array}$ \\
\hline Tariff & $\begin{array}{l}-0.0257^{* * *} \\
(0.0081)\end{array}$ & $\begin{array}{c}0.0088 \\
(0.0201)\end{array}$ & $\begin{array}{l}-0.1117 * * * \\
(0.0265)\end{array}$ & $\begin{array}{l}-0.0238^{* * *} \\
(0.0074)\end{array}$ & $\begin{array}{c}0.0076 \\
(0.0247)\end{array}$ & $\begin{array}{l}-0.1022 * * * \\
(0.0273)\end{array}$ \\
\hline Dum_EEA & $\begin{array}{c}0.7730^{* *} \\
(0.3356)\end{array}$ & $\begin{array}{l}1.8261^{* * *} \\
(0.3255)\end{array}$ & $\begin{array}{l}1.7544 * * * \\
(0.3229)\end{array}$ & $\begin{array}{c}0.6114^{*} \\
(0.3119)\end{array}$ & $\begin{array}{l}1.5475^{* * *} \\
(0.3464)\end{array}$ & $\begin{array}{l}1.2512^{* * *} \\
(0.2705)\end{array}$ \\
\hline Dum_contig & $\begin{array}{l}1.4652 * * * \\
(0.3385)\end{array}$ & $\begin{array}{l}1.3353 * * * \\
(0.3728)\end{array}$ & $\begin{array}{l}1.4510^{* * *} \\
(0.3328)\end{array}$ & $\begin{array}{l}1.3194 * * * \\
(0.3282)\end{array}$ & $\begin{array}{l}1.1916^{* * *} \\
(0.3594)\end{array}$ & $\begin{array}{l}1.0332 * * * \\
(0.2941)\end{array}$ \\
\hline Dum_landl & $\begin{array}{c}0.3371 \\
(0.3763)\end{array}$ & $\begin{array}{c}0.2764 \\
(0.2629)\end{array}$ & $\begin{array}{l}-0.8304 * * * \\
(0.2488)\end{array}$ & $\begin{array}{c}0.2039 \\
(0.3893)\end{array}$ & $\begin{array}{c}0.1896 \\
(0.2819)\end{array}$ & $\begin{array}{l}-0.4310^{*} \\
(0.2326)\end{array}$ \\
\hline constant & $\begin{array}{l}5.94466^{* * *} \\
(1.5898) \\
\end{array}$ & $\begin{array}{r}2.3563^{*} \\
(1.3491) \\
\end{array}$ & $\begin{array}{l}5.9060^{* * *} \\
(1.4289)\end{array}$ & $\begin{array}{l}6.9755^{* * *} \\
(1.4679) \\
\end{array}$ & $\begin{array}{c}2.8662^{* *} \\
(1.4448) \\
\end{array}$ & $\begin{array}{l}6.5933^{* * *} \\
(1.2321) \\
\end{array}$ \\
\hline $\mathrm{n}$ & 268 & 464 & 641 & 268 & 464 & 641 \\
\hline $\mathrm{R}^{2}$ & 0.8249 & 0.8205 & 0.8007 & 0.8173 & 0.8037 & 0.8022 \\
\hline Adjusted $\mathrm{R}^{2}$ & 0.8202 & 0.8177 & 0.7985 & 0.8124 & 0.8007 & 0.8000 \\
\hline St. error & 1.6005 & 2.0387 & 2.2671 & 1.6332 & 2.1365 & 2.2162 \\
\hline
\end{tabular}

Notes: IIT $_{1}$ - intra-industry trade calculated using the Grubel-Lloyd index adjusted for trade imbalances.

$\mathrm{IIT}_{2}$ - intra-industry trade calculated using the standard Grubel-Lloyd index.

Robust standard errors in brackets.

* significant at the $10 \%, * * 5 \%, * * * 1 \%$ level.

Source: Own calculations.

Moreover, as was already shown in Section 4, intra-industry trade in the region was on a lower level than it is today.

We estimate the values of trade elasticity of GDP similarity to be between 0.33 and 0.48 . This theoretically means that a $1 \%$ increase in GDP similarity between two countries leads to a 0.33 to 0.48 increase in mutual intra-industry trade volume. For example, other things being equal, if Hungarian GDP increased by $1 \%$ or the Chilean GDP per capita fell by $1 \%$, mutual trade between Hungary and Chile would increase in the range of 0.33 to $0.48 \%$. Obviously, in reality this might or might not be true due to the impossibility of maintaining the ceteris paribus assumption.

Other variables included in the model that show consistent statistical significance include EEA membership and contiguousness. The Visegrad countries tend 
to trade more with members of the EEA than with other countries, even when controlled for distance and economic size. The importance of this variable has increased over time and is today much higher than in the 1990s. Contiguousness (common land border) is also an essential driver of trade in the Visegrad region, although it appears that its role has been on the decline. The negative impact of tariffs and landlockedness on trade conforms to the expectations. The role of landlockedness is weak, yet when significant, its coefficient always has the expected negative sign. This demonstrates that it is usually easier to trade with coastal states rather than with landlocked states. The low statistical significance of the variable might be easily explained by high volumes of intra-Visegrad trade and the fact that with the exception of Poland, no other Visegrad country has direct access to the sea. The insignificant coefficient of the tariff variable in 2003 has presumably been caused by inconsistencies in the tariff data.

\subsection{Tobit regression}

Due to the drawbacks of the OLS regression, which were mentioned in Section 3.5, the Tobit regression is conducted using the same data (Table 4). The results are comparable to the OLS model. The coefficients on the income similarity variable are positive and statistically highly significant for both 2003 and 2013, indicating the validity of the Linder hypothesis. Coefficients of all the other independent variables have the same sign and a similar level of statistical significance as before.

\subsection{Robustness checks}

To check the robustness of the empirical results, several additional regressions were run. All tests were conducted on data from 2013 using intra-industry trade adjusted for trade imbalances as the dependent variable. In the first of the tests, outliers, defined as values that differ from the mean by more than 2 standard deviations, were excluded from the data. In the second test, intra-Visegrad trade was dropped from the analysis; in the third test, trade with EEA countries was excluded. This is based on the assumption that intra-Visegrad and intra-EEA trades might be influenced by a different set of rules than trade with other countries of the world, and hence could have significantly altered the results of our research. In the fourth and fifth tests, alternative indicators of distance are used - simple great circle distance between main agglomerations and remoteness (calculated as a weighted average of the distance of the country to all its trading partners). In the 
Table 4. Tobit regression results

\begin{tabular}{lcccccc}
\hline & \multicolumn{3}{c}{ Dependent variable: $\ln _{-}$IIT $_{1}$} & \multicolumn{3}{c}{ Dependent variable: $\ln _{-}$IIT $_{2}$} \\
& $(1)$ & $(2)$ & $(3)$ & $(4)$ & $(5)$ & $(6)$ \\
& 1995 & 2003 & 2013 & 1995 & 2003 & 2013 \\
\hline ln_GPD & $1.2266^{* * *}$ & $1.6752^{* * *}$ & $1.5123^{* * *}$ & $1.2380^{* * *}$ & $1.6721^{* * *}$ & $1.5370^{* * *}$ \\
& $(0.0532)$ & $(0.0529)$ & $(0.0506)$ & $(0.0512)$ & $(0.0500)$ & $(0.0516)$ \\
ln_Dist & $-1.6212^{* * *}$ & $-1.5991^{* * *}$ & $-1.6790^{* * *}$ & $-1.5294^{* * *}$ & $-1.5802^{* * *}$ & $-1.6900^{* * *}$ \\
& $(0.1560)$ & $(0.1555)$ & $(0.1370)$ & $(0.1634)$ & $(0.1470)$ & $(0.1546)$ \\
ln_GDPsim & 0.0612 & $0.4709^{* * *}$ & $0.3718^{* * *}$ & 0.0784 & $0.4587 * * *$ & $0.2813^{* *}$ \\
& $(0.1611)$ & $(0.1419)$ & $(0.1258)$ & $(0.1561)$ & $(0.1370)$ & $(0.1293)$ \\
Tariff & $-0.0266^{* * *}$ & 0.0112 & $-0.0776^{* *}$ & $-0.0290^{* * *}$ & 0.0129 & $-0.0857^{* * *}$ \\
& $(0.0069)$ & $(0.0259)$ & $(0.0322)$ & $(0.0073)$ & $(0.0213)$ & $(0.0326)$ \\
Dum_EEA & $0.5328^{*}$ & $1.2397 * * *$ & $1.0299^{* * *}$ & $0.6853^{* *}$ & $1.5036^{* * *}$ & $1.4806^{* * *}$ \\
& $(0.3083)$ & $(0.3560)$ & $(0.2789)$ & $(0.3290)$ & $(0.3330)$ & $(0.3304)$ \\
Dum_contig & $1.1618^{* * *}$ & $0.8160^{* *}$ & $0.6140^{*}$ & $1.3054^{* * *}$ & $0.9272^{* *}$ & $0.9402^{* * *}$ \\
& $(0.3328)$ & $(0.3974)$ & $(0.3279)$ & $(0.3407)$ & $(0.4108)$ & $(0.3633)$ \\
Dum_landl & 0.2508 & 0.4129 & -0.1097 & 0.3820 & 0.5482 & $-0.4688^{*}$ \\
& $(0.4043)$ & $(0.3248)$ & $(0.2566)$ & $(0.3916)$ & $(0.3034)$ & $(0.2806)$ \\
constant & $7.0064^{* * *}$ & 2.3210 & $5.3994^{* * *}$ & $5.9997^{* * *}$ & 1.8123 & $4.5549^{* * *}$ \\
& $(1.4702)$ & $(1.5037)$ & $(1.2654)$ & $(1.5768)$ & $(1.4083)$ & $(1.4761)$ \\
\hline $\mathrm{n}$ & 268 & 464 & 641 & 268 & 464 & 641 \\
\hline
\end{tabular}

Notes: IIT ${ }_{1}$ - intra-industry trade calculated using the Grubel-Lloyd index adjusted for trade imbalances. $\mathrm{IIT}_{2}$ - intra-industry trade calculated using the standard Grubel-Lloyd index.

Robust standard errors in brackets.

* significant at the $10 \%, * * 5 \%, * * * 1 \%$ level.

Source: Own calculations.

sixth and seventh tests, alternative GDP similarity variables are used - absolute difference between nominal GDPs and ratio of the difference in per capita GDP to the sum of exporting and importing country's per capita GDPs (as in Chow 2002). The results of the OLS regressions are presented in Table 5.

The reported robustness checks show that the link between income similarity and intra-industry trade is consistently strong and statistically significant. This remains true even when GDP similarity variables are substituted by alternative GDP difference variables (columns 6 and 7); obviously, in these cases, negative coefficients were expected. Coefficients on all other independent variables remain the same as in the main OLS and Tobit regressions. Hence, it appears that our model is robust.

Remarkably, when intra-Visegrad trade is excluded from the data (column 2), landlockedness becomes a highly statistically significant trade variable. This confirms our presumption that it was this regional trade that negatively affected this variable in the main models. 
Table 5. Robustness checks

\begin{tabular}{|c|c|c|c|c|c|c|c|}
\hline & \multicolumn{7}{|c|}{ Dependent variable: $\ln \_$IIT $_{1}, 2013$} \\
\hline & (1) & (2) & (3) & (4) & (5) & (6) & (7) \\
\hline ln_GPD & $\begin{array}{l}1.2830 * * * \\
(0.0604)\end{array}$ & $\begin{array}{l}1.3632 * * * \\
(0.0582)\end{array}$ & $\begin{array}{l}1.3419 * * * \\
(0.0742)\end{array}$ & $\begin{array}{l}1.3065^{* * *} \\
(0.0598)\end{array}$ & $\begin{array}{l}1.2820^{* * * *} \\
(0.0610)\end{array}$ & $\begin{array}{l}1.3577 * * * \\
(0.0604)\end{array}$ & $\begin{array}{l}1.3229 * * * \\
(0.0599)\end{array}$ \\
\hline ln_Dist & $\begin{array}{l}-1.4957 * * * \\
(0.1388)\end{array}$ & $\begin{array}{l}-1.5168^{* * *} \\
(0.1614)\end{array}$ & $\begin{array}{l}-1.4592 * * * \\
(0.1560)\end{array}$ & $\begin{array}{l}-1.4697^{* * *} \\
(0.1398)\end{array}$ & $\begin{array}{l}-11.007 * * * \\
(3.6609)\end{array}$ & $\begin{array}{l}-1.5152 * * * \\
(0.1407)\end{array}$ & $\begin{array}{l}-1.5259^{* * *} \\
(0.1409)\end{array}$ \\
\hline ln_GDPsim & $\begin{array}{l}0.3642 * * * \\
(0.1266)\end{array}$ & $\begin{array}{c}0.2638^{*} \\
(0.1353)\end{array}$ & $\begin{array}{c}0.3522 * * \\
(0.1438)\end{array}$ & $\begin{array}{l}0.4016 \text { *** } \\
(0.1294)\end{array}$ & $\begin{array}{l}0.3808^{* * *} \\
(0.1317)\end{array}$ & - & - \\
\hline GDPdif & - & - & - & - & - & $\begin{array}{c}-0.0001^{* *} \\
(0.0000)\end{array}$ & $\begin{array}{c}-1.1575^{* *} \\
(0.4583)\end{array}$ \\
\hline Tariff & $\begin{array}{c}-0.0883^{* * *} \\
(0.0294)\end{array}$ & $\begin{array}{c}-0.1058^{* * * *} \\
(0.0311)\end{array}$ & $\begin{array}{c}-0.0977^{* * *} \\
(0.0310)\end{array}$ & $\begin{array}{l}-0.1020^{* * *} \\
(0.0294)\end{array}$ & $\begin{array}{c}-0.1232 * * * \\
(0.0311)\end{array}$ & $\begin{array}{l}-0.1153^{* * *} \\
(0.0302)\end{array}$ & $\begin{array}{c}-0.1071^{* * *} \\
(0.0297)\end{array}$ \\
\hline Dum_EEA & $\begin{array}{l}1.2007^{* * *} \\
(0.2679)\end{array}$ & $\begin{array}{l}1.5481^{* * *} \\
(0.3362)\end{array}$ & - & $\begin{array}{l}1.2190^{* * *} \\
(0.2712)\end{array}$ & $\begin{array}{l}3.1317^{* * *} \\
(0.2498)\end{array}$ & $\begin{array}{l}1.3567^{* * *} \\
(0.2747)\end{array}$ & $\begin{array}{l}1.1042 * * * \\
(0.2772)\end{array}$ \\
\hline Dum_contig & $\begin{array}{l}1.0688^{* * *} \\
(0.3172)\end{array}$ & $\begin{array}{l}1.2657^{* * *} \\
(0.3728)\end{array}$ & $\begin{array}{l}1.5734 * * * \\
(0.4776)\end{array}$ & $\begin{array}{l}1.0278^{* * *} \\
(0.3145)\end{array}$ & $\begin{array}{l}2.9811^{* * *} \\
(0.3021)\end{array}$ & $\begin{array}{l}0.9602^{* * *} \\
(0.3219)\end{array}$ & $\begin{array}{l}0.9187 * * * \\
(0.3156)\end{array}$ \\
\hline Dum_landl & $\begin{array}{c}-0.4868^{*} \\
(0.3172)\end{array}$ & $\begin{array}{l}-0.8593^{* * *} \\
(0.3049)\end{array}$ & $\begin{array}{c}-0.4319 \\
(0.3001)\end{array}$ & $\begin{array}{c}-0.3275 \\
(0.2540)\end{array}$ & $\begin{array}{c}0.0672 \\
(0.2880)\end{array}$ & $\begin{array}{l}-0.5862^{* *} \\
(0.2500)\end{array}$ & $\begin{array}{c}-0.4433 * \\
(0.2519)\end{array}$ \\
\hline constant & $\begin{array}{l}6.7672 * * * \\
(1.2089)\end{array}$ & $\begin{array}{l}5.3489 * * * \\
(1.4834)\end{array}$ & $\begin{array}{c}5.7696^{* * *} \\
(1.3568)\end{array}$ & $\begin{array}{c}6.3386^{* * *} \\
(1.2346) \\
\end{array}$ & $\begin{array}{c}-5.1394 * * * \\
(0.8759)\end{array}$ & $\begin{array}{c}5.8902 * * * \\
(1.1873) \\
\end{array}$ & $\begin{array}{l}6.7310^{* * *} \\
(1.2446)\end{array}$ \\
\hline $\mathrm{n}$ & 566 & 564 & 460 & 580 & 580 & 576 & 576 \\
\hline $\mathrm{R}^{2}$ & 0.7501 & 0.7435 & 0.6339 & 0.7558 & 0.7156 & 0.7534 & 0.7556 \\
\hline Adjusted $\mathrm{R}^{2}$ & 0.7469 & 0.7403 & 0.6290 & 0.7529 & 0.7121 & 0.7504 & 0.7526 \\
\hline St. error & 2.2808 & 2.4794 & 2.5462 & 2.3289 & 2.5136 & 2.3478 & 2.3375 \\
\hline
\end{tabular}

Notes: Columns (1) Outliers excluded (2 standard deviations). (2) Intra-Visegrad trade excluded. (3) EEA countries excluded. (4) Simple great circle distance between main agglomerations used as the distance variable. (5) Remoteness used as the distance variable. (6) Absolute difference between nominal GDPs used as the income similarity variable (negative sign of GDPdif expected). (7) Ratio of the difference in per capita GDP to the sum of exporting and importing country's per capita GDPs used as the income similarity variable (negative sign of GDPdif expected).

Robust standard errors in brackets.

* significant at the $10 \%, * * 5 \%, * * * 1 \%$ level.

Source: Own calculations.

\subsection{Implications for policymakers}

Intra-industry trade constitutes $60-70 \%$ of the total trade of the Visegrad countries. Small domestic markets and high trade openness mean that the role of intraindustry trade cannot be overestimated. As a result, studies focusing on the determinants of IIT are of substantial importance.

Apart from the contributions to the empirical testing of the Linder hypothesis, our research has valuable implications for policymakers. While standard determinants of trade such as GDP, distance, or tariffs have been confirmed as important drivers of trade in the Visegrad region in numerous papers, GDP similarity had 
not been applied in previous research. From a theoretical perspective, our research indicates that in countries with a high share of intra-industry trade, gravity models of trade that do not include a variable of GDP similarity might be biased. They tend to underestimate trade with similar economies and overestimate trade with considerably richer or poorer countries. Given that a broad range of literature builds on the Linder hypothesis and supports its validity, and taking into account how popular gravity models are among economists and policymakers alike, it is highly recommended that future models incorporate a GDP similarity variable to achieve more accurate results and to be able to prepare more realistic strategies. For example, Slovakia's current export strategy emphasizes the goal of diversifying exports, focusing more on countries such as Turkey, Vietnam, India, Malaysia, Serbia, and Croatia (MFA 2013). However, with the exception of Croatia, our model indicates that the volume of Slovakia's intra-industry trade with these countries is close to its theoretical values. If the government wants to focus on intra-industry trade (as it has declared), the emphasis should be on trade and investment policies oriented towards a different set of countries, as identified by our model: Canada, Mexico, or Israel. Similar recommendations can be made for other Visegrad countries (Table 6).

Another interesting finding of our model relates to the development of the EEA and distance coefficients over time. The results show that while the importance of the European integration for the Visegrad trade increased and the importance of distance decreased in the transition period of the 1990s, the trend reversed between 2003 and 2013. This might be a result of the global economic crisis, but it also might be a demonstration of the so-called "distance puzzle" (the empirical result that the estimated coefficient of distance on the volume of trade is generally found to increase in time rather than decrease). Further analyses based on annual data must be conducted to confirm this claim.

\subsection{Drawbacks}

While taking numerous steps to minimise bias in data analysis, our approach is not without inaccuracies. First, due to poor data availability for many products, we opted to use aggregate bilateral trade data instead of disaggregate productlevel data. Second, there is a well-known issue with zero trade flows, which cannot be resolved satisfactorily. However, none of these problems threatens the validity of our results. Taking into account Hallak's (2010) finding that "aggregation across sectors induces a systematic bias against finding support for Linder's quality-base theory", it follows immediately that if a test based on aggregate data 
Table 6. Trade partners with the highest potential for further development of intra-industry exports

\begin{tabular}{llll}
\hline Country & Current partners & New partners (EEA) & New partners (world) \\
\hline Czech Republic & Germany & Norway & Mexico \\
& Poland & Greece & Chile \\
& Austria & Croatia & Jordan \\
& Italy & Denmark & Myanmar \\
& France & Cyprus & Guatemala \\
& United Kingdom & Iceland & Uruguay \\
\hline Hungary & Italy & Greece & Albania \\
& Austria & Norway & Lebanon \\
& United Kingdom & Finland & Peru \\
& France & Latvia & Chile \\
& Croatia & Ireland & Argentina \\
& Romania & Cyprus & Georgia \\
\hline Poland & Germany & Greece & Myanmar \\
& Russian Federation & Croatia & Guatemala \\
& & Andorra & Ghana \\
& & & Albania \\
& & & Jamaica \\
& & Paraguay \\
\hline Slovakia & Poland & Norway & Ukraine \\
& Austria & Greece & Canada \\
& Italy & Denmark & Mexico \\
& France & Croatia & Israel \\
& Germany & Finland & Australia \\
& United Kingdom & Ireland & Argentina \\
\hline
\end{tabular}

Notes: Current partners are export destinations with a more than $1 \%$ share on total exports. New partners are export destinations with a lower share on total exports. Oil-exporting countries were excluded from the table.

Source: Own research based on the gravity model of trade used in this paper.

finds support for the theory, this support is more significant than one from tests based on disaggregate data. Moreover, as there is an additional small bias against the hypothesis in our treatment of zero trade flows, statistically significant results of our research indicate that the evidence in favour of the hypothesis is strong.

Much more powerful results could be arrived at by using firm-level data. However, this has not been made available in the Central European region, mainly due to confidentiality concerns - trade is relatively highly concentrated and even anonymised data would indirectly disclose the identity of exporters or importers. Consequently, statistical offices are hesitant to provide data on the majority of sectors (such as automotive or electronics). 


\section{CONCLUSION}

In the present paper, the empirical validity of the Linder hypothesis in the Visegrad countries has been studied. Using a variant of the gravity model of trade, we have found that controlling for other factors, the Visegrad countries tend to trade more with countries with similar per capita income levels than with significantly richer or poorer countries. This observation is consistent with the Linder hypothesis and has been confirmed by robustness checks.

The Visegrad countries have one of the highest shares of intra-industry trade among total trade in the world. The roles of consumer preferences and vertical trade have been strong and it is interesting to see that the trade patterns are in line with Linder's predictions. The results of our research have important implications for policymakers. They can be used for efficiently planning export promotion policies and for more targeted investment promotion activities. It appears that the role of intra-industry trade in the Visegrad region has still been growing; knowing its determinants and sources can help governments maximise welfare.

Possible future research includes testing the hypothesis with more disaggregate data, for a wider time period, and with a more complex tariff data set.

\section{REFERENCES}

Aquino, A. (1978): Intra-Industry Trade and Inter-Industry Specialization as Concurrent Sources of International Trade in Manufactures. Weltwirtschaftliches Archiv, 114(2): 275-296.

Bergstrand, J. H. (1990): The Heckscher-Ohlin-Samuelson Model, the Linder Hypothesis and the Determinants of Bilateral Intra-Industry Trade. Economic Journal, 100(403): 1216-1229.

Bojnec, S. - Fertő, I. - Jámbor, A. - Tóth, J. (2014): Determinants of Technical Efficiency in Agriculture in New EU Member States from Central and Eastern Europe. Acta Oeconomica, 64(2): 197-214.

Brülhart, M. (2009): An Account of Global Intra-Industry Trade 1962-2006. World Economy, 32(3): 401-459.

CEPII (2011): Geodist. Available Online: Http://Www.Cepii.Fr/CEPII/En/Bdd_Modele/ Presentation.Asp? Id $=6$.

Chow, Ch. (2002): Linder Hypothesis Revisited. Applied Economics Letters, 9(1): 601-605.

Chow, P. - Kellman, M. - Shachmurove, Y. (1999): A Test of the Linder Hypothesis in Pacific NIC Trade 1965-1990. Applied Economics, 31(2): 175-182.

Černoša, S. (2007): Horizontal and Vertical Intra-Industry Trade between the Former CEFTA Countries and the European Union. Managing Global Transitions, 5(2): 157-178.

Dudáš, T. (2004): Stav Politického Prostredia Ako Faktor Investičnej Atraktívnosti v Štátoch Strednej a Východnej Európy (Political Environment as a Factor of Investment Attractiveness in the Countries of Central and Eastern Europe). Medzinárodné Vzt'ahy, 2(2): 68-74.

Fertő, I. (2007): Intra-Industry Trade in Horizontally and Vertically Differentiated Agri-Food Products between Hungary and the EU. Acta Oeconomica, 57(2): 191-208. 
Francois, J. F. - Kaplan, S. (1996): Aggregate Demand Shifts, Income Distribution, and the Linder Hypothesis. Review of Economics and Statistics, 78(2): 244-250.

Grossman, G. M. - Rogoff, K. (1995): Handbook of International Economics. Volume 3. Amsterdam: North-Holland.

Grubel, H. G. - Lloyd, P. J. (1971): The Empirical Measurement of Intra-Industry Trade. Economic Record, 47(4): 494-517.

Grubel, H. G. - Lloyd, P. J. (1975): Intra-Industry Trade. The Theory and Measurement of International Trade in Differentiated Products. London: Macmillan.

Győrffy, D. (2009): Structural Change without Trust: Reform Cycles in Hungary and Slovakia. Acta Oeconomica, 59(2): 147-177.

Hallak, J. C. (2010): A Product-Quality View of the Linder Hypothesis. Review of Economics and Statistics, 92(3): 453-466.

Hanink, D. M. (1988): An Extended Linder Model of International Trade. Economic Geography, 64(4): 322-334.

Hanink, D. M. (1990): Linder, Again. Weltwirtschaftliches Archiv, 126(2): 257-267.

Hoftyzer, J. (1984): A Further Analysis of the Linder Trade Thesis. Quarterly Review of Economics and Business, 24(2): 57-70.

Jámbor, A. (2014): Country-Specific Determinants of Horizontal and Vertical Intra-Industry AgriFood Trade: The Case of the EU New Member States. Journal of Agricultural Economics, 65(3): 663-682.

Kawecka-Wyrzykowska, E. (2009): Evolving Pattern of Intra-Industry Trade Specialization of the New Member States of the EU: The Case of Automotive Industry. European Economy Economic Papers, 2009(364): 1-37.

Kennedy, T. E. - McHugh, R. (1980): An Intertemporal Test and Rejection of the Linder Hypothesis. Southern Economic Journal, 46(3): 898-903.

Lane, T. D. (1992): Transforming Poland's Economy. Finance \& Development, 29(2): 10-13.

Linder, S. (1961): An Essay on Trade and Transformation. Stockholm: Almqvist \& Wiksell.

Linnemann, H. - van Beers, C. (1988): Measures of Export-Import Similarity and the Linder Hypothesis Once Again. Weltwirtschaftliches Archiv, 124(3): 445-457.

McPherson, M. A. - Redfearn, M. R. - Tieslau, M. A. (2001): International Trade and Developing Countries: An Empirical Investigation of the Linder Hypothesis. Applied Economics, 33(1): 649-657.

Ministry of Foreign and European Affairs of the Slovak Republic (2013): Stratégia Podpory Exportu Slovenskej Republiky Na Obdobie 2014-2020 (Export Promotion Strategy of Slovakia for 2014-2020). Bratislava.

Tang, K. K. (2011): Correcting the Size Bias in Trade Openness and Globalization Measures. Global Economy Journal, 11(3): 1-23.

Thursby, J. G. - Thursby, M. C. (1987): Bilateral Trade Flows, the Linder Hypothesis, and Exchange Risk. Review of Economics and Statistics, 69(3): 488-495.

UNCTAD (2014): UNCTAD Stat. Available Online: Http://Unctadstat.Unctad.Org/Wds/ Reportfolders/Reportfolders.Aspx.

Vona, S. (1991): On the Measurement of Intra-Industry Trade: Some Further Thoughts. Weltwirtschaftliches Archiv, 127(4): 678-700.

World Bank (2014a): World Bank Data. Available Online: Http://Data.Worldbank.Org/.

World Bank (2014b): World Bank Analytical Classifications. Available Online: Http://Siteresources.Worldbank.Org/DATASTATISTICS/Resources/OGHIST.Xls. 
WTO (2012): A Practical Guide to Trade Policy Analysis. Geneve.

WTO (2014): World Trade Report 2014. Geneve.

Yoshida, Y. - Leitao, N. C. - Faustino, H. C. (2009): Vertical Intra-Industry Trade and Foreign Direct Investment between Japan and European Countries. Atlantic Economic Journal, 37(4): 351-365.

Zídek, L. (2014): Evaluation of Economic Transformation in Hungary. Review of Economic Perspectives, 14(1): 55-88. 